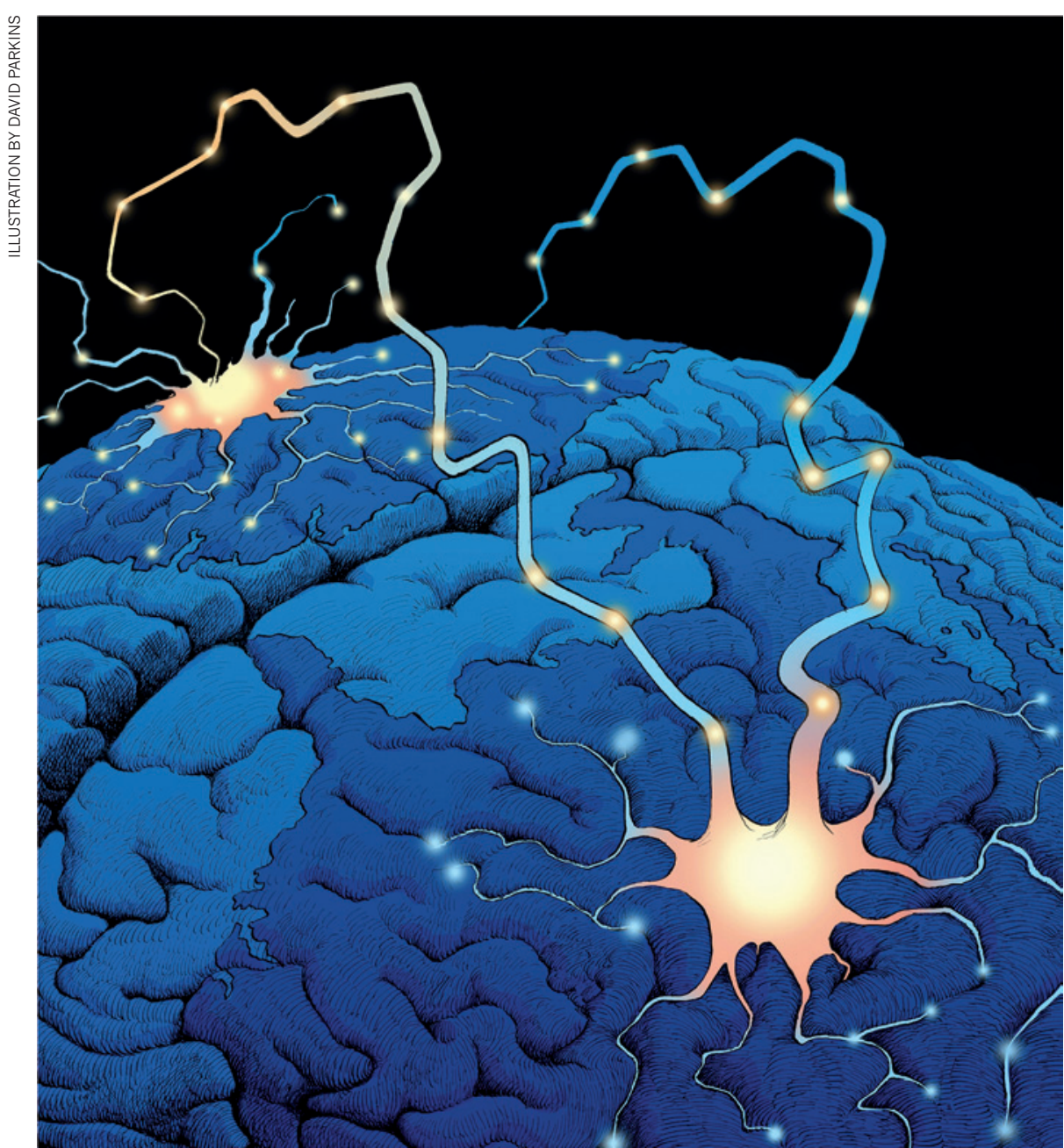

\section{Turning brain drain into brain circulation}

\section{Overseas scholarships that encourage scientists to return to their home countries are helping to rebuild science in Latin America, says Torsten Wiesel.}

$\mathrm{I}$ $\mathrm{t}$ takes a long time for a country to build a strong base in science, but only a short time to destroy it. Germany was a sad example. It was a world leader in the sciences for more than a century, until its science base was demolished during the Nazi era, and the country ceded its position to the United States. It has taken decades for Germany to rise again to its current level of excellence.
The German experience has much in common with the situation in Latin America, where authoritarian regimes came to power in the mid-twentieth century in countries including Brazil, Chile and Argentina. As a consequence, many of the continent's best scientists emigrated to the United States, Europe and Canada. When the dictatorships were finally shaken off in the 1980s and 1990s, the departed scientists were settled in their new homes and had little incentive to return to countries left laden with debt.

Many have forgotten that science in Latin America was once robust. For example, Bernardo Houssay, who won the 1947 Nobel Prize in Physiology or Medicine, directed the Institute of Physiology at Buenos Aires University until 1943, when the government fired him for advocating for democracy; his protégé, Luis Leloir, won the 1970 Nobel Prize in Chemistry. Several emigrants also became laureates, including the immunologist Baruj Benacerraf, from Venezuela, and the biochemist César Milstein, from Argentina.

Against this background, the Pew Latin American Fellows Program was founded to help to rebuild and strengthen biomedical sciences in the region. From its inception, the programme has been linked to the preexisting Pew Biomedical Scholars Program, which each year provides around 20 promising newly independent US scientists with four-year scholarships, funded by the Pew Charitable Trusts, a non-profit organization based in Philadelphia, Pennsylvania.

In March 1989, at the annual meeting of the scholars programme in Puerto Vallarta, Mexico, a group of these scholars - struck by the lack of resources of their counterparts in Mexico - sought help from Rebecca Rimel, president of the Pew Charitable Trusts. Later, Rebecca and I discussed the best ways to train talented students from Latin America, and our ideas crystallized into the fellows programme.

\section{REPATRIATION RATES}

Since the founding of the Pew Latin American Fellows Program in 1991, about ten graduate students each year have been awarded two-year postdoctoral fellowships to work in some of the best labs in North America. It is no surprise that some remain abroad to continue their careers in more developed countries. What is surprising is that more than $70 \%$ return to their home countries, which may not always allocate sufficient resources to cutting-edge research (see 'Bringing science home'). For comparison, the Human Frontier Science Program, a multinational initiative that supports the life sciences, also funds postdoctoral fellows worldwide - but fewer than half of those who train in the United States return to their home countries.

Pew fellows who remain in North America have positions in leading universities and several have established joint projects with labs in their home countries, as well as hosting new fellows. The annual

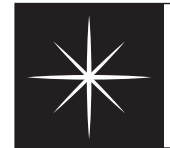

SOUTH AMERICAN SCIENCE A Nature special issue nature.com/southamerica 


\section{Bringing science home}

Becoming a great scientist requires exposure to greatness. At a 1997 orientation meeting in Costa Rica for new postdocs, Torsten Weisel, the co-founder of the Pew Latin American Fellows Program, told us that the best scientists are not necessarily more creative or smarter than everyone else, but that they had the opportunity in their junior years to conduct and discuss science in prime environments.

I earned my PhD in 1996 from the University of Chile in Santiago, studying how ions move through proteins extracted from neurons. I wanted to apply that work in living brains. Senior members in my department told me about the Latin American fellows programme and helped me to find a postdoctoral adviser.

Charles Zuker, then at the University of California, San Diego, accepted me into his lab and taught me to study how flies sense the world. It was an amazing experience to be in the Zuker lab when seminal work on taste and pressure receptors was happening. I was part of the team that helped to show how the organization of proteins in photoreceptor cells is essential for flies to see light. I returned home to work as a junior professor at the University of Chile in 1998.

Even now, few institutions in South America provide start-up funds to new faculty members. Most young professors have to join senior laboratories or sit in an empty lab, sometimes for more than a year, before getting their first grant. By contrast, I had a US $\$ 35,000$ repatriation fund from my Pew fellowship. The money was enough to buy small, essential equipment to start doing some simple experiments soon after I returned: a table-top centrifuge to separate cells into basic components, power supplies, electrophoresis chambers to run gels for DNA analysis, a mechanical shaker to grow bacteria and some reagents.

Since then, I have trained nearly two dozen students to work with flies and have helped four researchers to set up their own labs for fly research in Chile. I have also directed three international courses to train Latin American students to use the insects (and, more recently, worms) as animal models.

And my relationship with Pew continues. I have started collaborations with scientists from other countries whom I met at annual Pew alumni meetings. For the past five years, I have served on the regional Pew committee that selects six Chilean candidates for the fellowship. We look for young researchers who have connected with a great lab and proposed adventurous projects - particularly to work in areas or with animal models that are not available at home. The hope is that they will bring those skills back to their native countries.

Chile has an $80 \%$ repatriation rate. That bespeaks both a good selection process and the importance of the start-up money for returning fellows. Scientific agencies and governments in Latin America should try to replicate these measures to help to build a stronger and more innovative scientific community. Jimena Sierralta, University of Chile meetings are attended by Latin American fellows, biomedical scholars and senior advisers, including Nobel laureates and Howard Hughes Medical Institute scholars. Participants share ideas and start collaborations as a result of the meetings.

\section{SUCCESSFUL SCHOLARS}

In a survey sent out in 2013 to 202 alumni of the Latin American fellows programme between 1991 and 2011, an impressive 151 responded. Alumni who have returned to their home countries include department heads and university provosts. Nearly half reported holding a director position, such as department chair or head of an academic discipline. On average, each fellow had published 15 papers, and those who had returned home had trained 13 scientists, from technicians and graduate students to visiting scholars.

Last month, the journal Cell highlighted a 2003 Pew fellow, immunologist Dario Zamboni, as one of 40 notable scientists under 40 years old. Zamboni is head of the Innate Immunity and Microbial Pathogenesis laboratory at the University of São Paulo in Brazil. His group is working out how the body responds to intracellular parasites, including the one that causes Chagas disease - a problem in poor, rural areas of South America. Doing science in Brazil involves hurdles that would not exist in the United States, but he is determined to improve the system for other scientists in the country.

Selection of fellows starts with established researchers in Latin America. Argentina, Brazil, Chile and Mexico have national committees of former Pew fellows and senior scientists. Each committee selects six applicants by evaluating research proposals and interviewing a dozen or so of the most promising students. (The chairs of these committees act together as a fifth "The fellows multinational com"The fellows mittee for applicants programme is just a drop in the ocean relative to the need of the entire continent." from the other countries in the region.)

Thirty applications are chosen in total to be evaluated by a central committee of outstanding US scientists with strong ties to Latin America. Several are emigrants from the dark periods in their countries of origin. These committees work hard to select the most promising scholars and send them to the best labs.

The Brazilian state of São Paulo plans to augment the benefits that are open to returning Pew fellows: they can apply for a generous four-year stipend to get their new labs off the ground. The hope is that other nations will use their own resources to extend this initiative to foster their best scientists.
The absolute number of Latin American fellows is small - fewer than 250 in a region with more than 400 million people. But my impression is that they have an outsized influence, shaping expectations of what it means to be a scientist in Latin America, and the fellows' high expectations of themselves.

That said, the fellows programme is just a drop in the ocean relative to the need of the entire continent. This is perhaps especially true now that larger programmes exist in several Latin countries to support the training of scientists abroad and to encourage trained scientists to return home, such as the Brazil Scientific Mobility Program (see page 207).

Nonetheless, like a seed planted in a fertile soil, the Pew programme has flourished over the past 20 years. The plant will no doubt continue to grow and to support its ecosystem. The ultimate success would be that this type of programme is no longer needed because each country would have developed strong, independent scientific establishments. But for now, we need to bolster the support for scientists in emerging countries, in Latin America and elsewhere.

Torsten Wiesel is president emeritus of Rockefeller University in New York City, USA. He won the 1981 Nobel Prize in Physiology or Medicine. e-mail:wiesel@rockefeller.edu 